UDC 514.18

\title{
SYSTEM OF MODELING OF STRUCTURAL ELEMENTS OF VENTILATION SYSTEMS BY POLYCOORDINATE TRANSFORMATIONS
}

\author{
Iu.V. Sydorenko, \\ Ph.D. \\ O.V. Kryvda, \\ Ph.D. \\ National Technical University of Ukraine "Igor Sikorsky Kyiv Polytechnic Institute", \\ I.V. Leshchynska, \\ job seeker Department of Management in Construction \\ Kyiv National University of Construction and Architecture
}

DOI: $10.32347 / 2410-2547.2020 .104 .221-228$

\begin{abstract}
In this work, a computer system for modeling geometric objects is constructed. This system is instrumental in solving various problems that occur in construction, in particular in the design of ventilation systems. Our approach is based on a method of the polypoint transformations, namely on deformation modeling. Deformations of geometric objects could be described based on the given parameters of a dynamic deformation rather than on analytical equations. An object's form is changing due to a deformation of a space in which an object is located. Using the machinery of the polypoint transformations, a computer system for modeling geometric objects has been created. The system provides tools that simplify the constriction of surfaces with various types of sections.

Key words: deformation modeling, polypoint transformations, computer modeling, ventilation system, gearbox.
\end{abstract}

1. Introduction. There are various ways to supply and remove indoor air. The choice of ventilation system must take into account technological requirements for working conditions and living space, as well as economic factors. When designing ventilation, it is necessary to apply appropriate design and planning solutions using modern information technologies.

The composition of the system depends on its type. One of the most commonly used is mechanical systems. They include the following components: ducts; grates; diffusers; fans; heaters; filters, gearboxes and more. In any ventilation, ducts are an important structural element for supplying fresh air and removing polluted air. When designing ducts in construction, it is necessary to take into account the various forms of cross sections when connecting ducts, which is difficult in practice. Similar problems also arise when designing gearboxes, various ventilation systems for residential and domestic industrial premises.

The difficulty of this task is that the transitional structures listed may have cross-sections of different shapes at the ends that need to be joined: for example, round on one side and square on the other. This problem will be solved by creating a system of modeling by means of polycoordinate transformations.

(C) Sydorenko Iu.V., Kryvda O.V., Leshchynska I.V. 
2. Literature Review and the Problem Statement. In [1] formulas of polypoint transformations are given, the concept of poly-point coordinates is introduced and the method of transformation of a straight line in a point cascade is described.

$[2,3]$ provides examples of how poly-point transforms are used to control the shape of an object. The analysis of different ways of polypoint transformations is carried out.

[4] provides an example of the use of different types of polypoint transformations to solve the extrapolation problem.

The analysis of these studies indicates the need to create a computer system for modeling geometric objects, which would allow solving a number of problems that arise in the design and design in construction.

3. Formulating the goals of the article. The purpose of this study is a computer-aided system for modeling geometric objects, which is based on the theory of polypoint transformations, created with the help of modern information technologies, which would greatly simplify the existing processes of constructing surfaces with different types of sections.

4. Main Materials of the Study. Polycoordinate transformations [1] can be used in various fields of production at the stage of modeling of investigated processes. Polycoordinate transformations are divided into polytissues and polypoint.

Let's take a closer look at polypoint transformations using a multipoint framework (Figure 1).
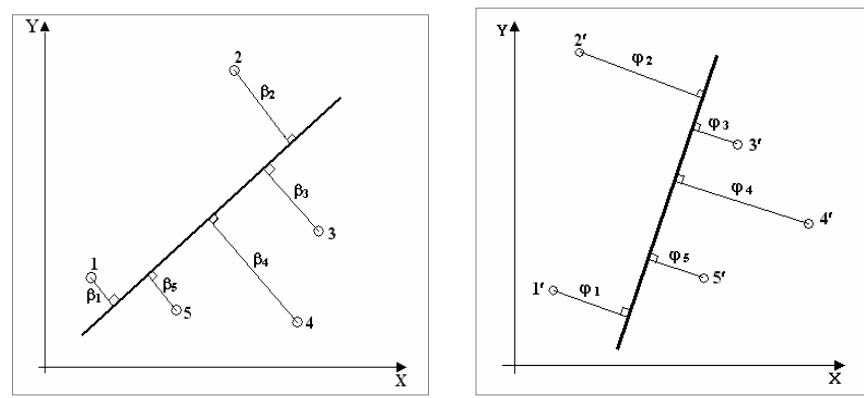

Fig. 1. Polypoint transformations on a plane

Polypoint transformations allow you to change the position of a straight line (object of transformation) by manipulating the points of the transformation base. As can be seen from Figure 1, the initial base (points 1,2,3,4,5) was changed to $1^{\prime}, 2^{\prime}, 3^{\prime}, 4^{\prime}, 5^{\prime}$. In this case, the position of the line changed according to the change in the basis of points.

This is achieved by decoupling the system, which establishes a functional relationship between the polycoordinate coefficients of the direct before and after transformations $\left(\beta_{i}\right.$ and $\left.\varphi_{i}\right)$. 
Since polypoint transformations allow one line to be transferred from the initial basis to another, two and several lines can be "transferred" in the same way. This, in turn, means that you can transform objects in this way. Figure 2 shows the polypoint circle transformation. As you move the points, the circle turns into a closed curve.

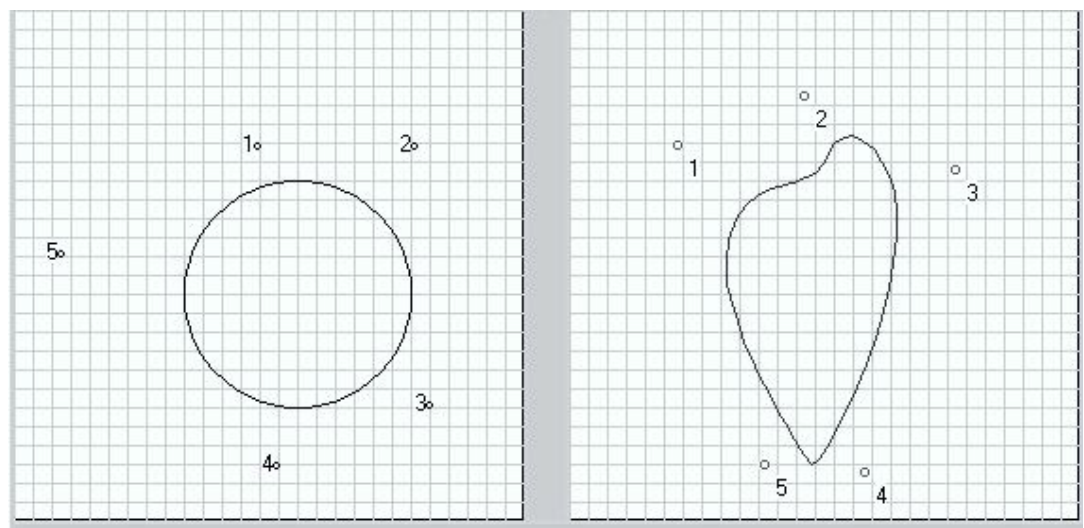

Fig. 2. Conversion of a circle at the five-point base

Thus, polypoint transformations allow you to track the deformation of a geometric object, affecting only the space that limits that object. There are different ways of influencing the basis [2, 3]. For example, you can move the basis points in the plane, and you can enter and manipulate the weights by increasing or decreasing the weight at a particular point of the basis, or at all points in the same way. Figure 3 shows an example of a circle (object of transformation) with a change of weight is converted into a square (with increasing weight), or a curvilinear rhombus (with decreasing weight).

In three-dimensional polypoint transformations, the images will be not planes but straight. Two point bases are introduced: initial and converted. As the weights of the basis points change, the shape of the three-dimensional objects changes. These transformations also have different modifications depending on the appearance of the scales.

Let's take a closer look at polypoint transforms using a multipoint frame.

The plane in the initial basis can be described by a system of equations:

$\gamma_{i}=a x_{i}+b y_{i}+c z_{i}+d h_{i}, i=1 \ldots n$.

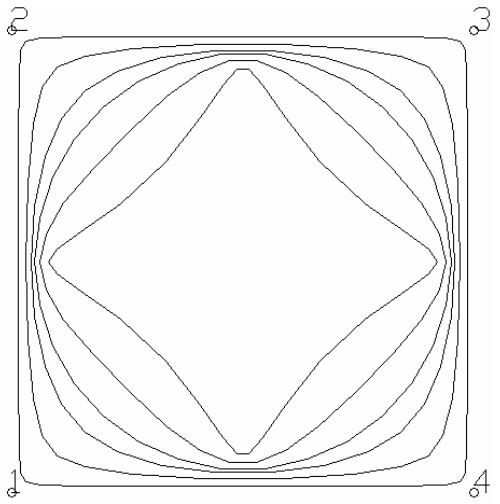

Fig. 3. Weight transformations of a circle at a four point basis

The area after conversion will be determined by such a system: 


$$
\varphi_{i}=A X_{i}+B Y_{i}+C Z_{i}+D H_{i}, i=1 \ldots n,
$$

where $\varphi_{i}-$ the distance from the plane (the prototype) to the points in the initial base.

The system determines $A, B, C, D$ - coefficients of the transformed plane.

The formula of multipoint transformation is written as:

$$
\varphi_{i}=\omega_{i} \gamma_{i}, i=1 \ldots n \text {. }
$$

So,

$$
\omega_{i} \gamma_{i}=A x_{i}+B y_{i}+C z_{i}+D h_{i}, i=1 \ldots n .
$$

Functional for unambiguously solving the problem:

$$
\sum\left(\varphi_{i}-\gamma_{i}\right)^{2} \rightarrow 0, i=1 \ldots n \text {. }
$$

Therefore, it is necessary to find partial derivatives for all four variables.

$$
\begin{aligned}
& \frac{\partial \sum\left(\varphi_{i}-\gamma_{i}\right)^{2}}{\partial A}=2 \sum X_{i}\left(A X_{i}+B Y_{i}+C Z_{i}+D H_{i}-\gamma_{i}\right)=0, \\
& \frac{\partial \sum\left(\varphi_{i}-\gamma_{i}\right)^{2}}{\partial B}=2 \sum Y_{i}\left(A X_{i}+B Y_{i}+C Z_{i}+D H_{i}-\gamma_{i}\right)=0, \\
& \frac{\partial \sum\left(\varphi_{i}-\gamma_{i}\right)^{2}}{\partial C}=2 \sum Z_{i}\left(A X_{i}+B Y_{i}+C Z_{i}+D H_{i}-\gamma_{i}\right)=0, \\
& \frac{\partial \sum\left(\varphi_{i}-\gamma_{i}\right)^{2}}{\partial D}=2 \sum H_{i}\left(A X_{i}+B Y_{i}+C Z_{i}+D H_{i}-\gamma_{i}\right)=0 .
\end{aligned}
$$

These four equations form a linear system of equations.

$$
A \cdot V=B,
$$

where

$$
\begin{gathered}
A=\left[\begin{array}{cccc}
\sum X_{i}^{2} & \sum X_{i} Y_{i} & \sum X_{i} Z_{i} & \sum X_{i} H_{i} \\
\sum Y_{i} X_{i} & \sum Y_{i}^{2} & \sum Y_{i} Z_{i} & \sum Y_{i} H_{i} \\
\sum Z_{i} X_{i} & \sum Z_{i} Y_{i} & \sum Z_{i}^{2} & \sum Z_{i} H_{i} \\
\sum H_{i} X_{i} & \sum H_{i} Y_{i} & \sum H_{i} Z_{i} & \sum H_{i}^{2}
\end{array}\right], \\
V=\left[\begin{array}{c}
A \\
B \\
C \\
D
\end{array}\right], B=\left[\begin{array}{c}
\sum X_{i} \gamma_{i} \\
\sum Y_{i} \gamma_{i} \\
\sum Z_{i} \gamma_{i} \\
\sum H_{i} \gamma_{i}
\end{array}\right] .
\end{gathered}
$$

Unleashing the system, we get the values $A, B, C, D$ - the coefficients of the plane after conversion.

The algorithm for converting a three-dimensional body can be described as follows:

- the 3D object is immersed in a point base. This is done by the user by selecting the basis points based on the conditions imposed on the task, such as the final shape of the object; 
- the body to be deformed is represented by a set of planes (triangles). This can be done, for example, by triangulation;

- consecutive polypoint transformations of each plane are performed and their intersection is determined;

- using the existing methods of spatial interpolation (or the capabilities of modern graphics packages) smoothies the resulting surface.

Figure 4 shows an example of a deformation of a sphere as the basis weights change.

The polypoint transformations considered allow modeling of deformations of different geometric elements. Exterior, modeling gearboxes (adapters) with different breaks in front of different limbs, which allow to connect with each other the ducts of different system ventilations of internal living and industrial premises. Examples of some reducers are presented in Figure 5.

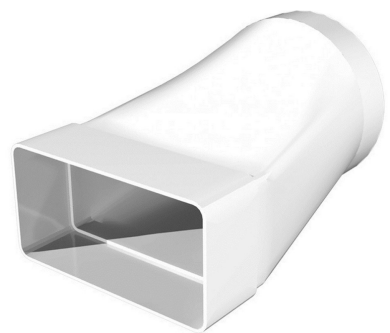

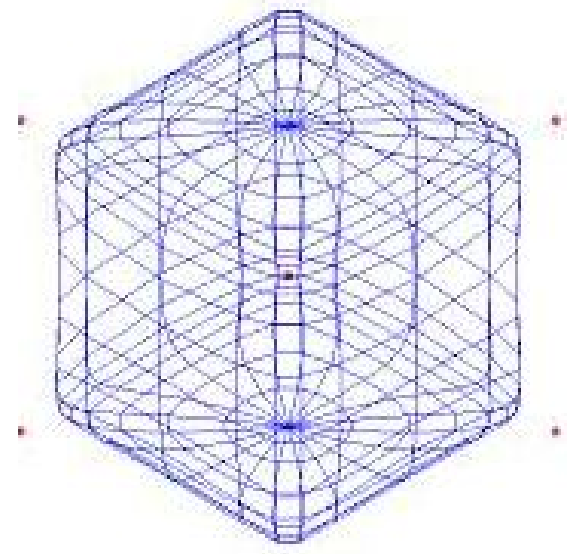

Fig. 4. Three-dimensional poly-point transformations

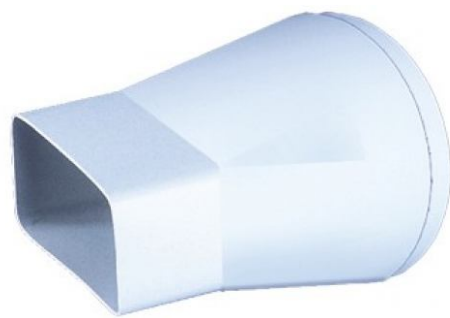

Fig. 5. Gearboxes with rectangular and circular sections

To visualize the processes of deformation of an object on the basis of polypoint transformations, a system has been developed that allows to control the positions of the basis points, ie their coordinates, and also to set the weights of these points. The system lets you view the animation. The object rotates around three axes in real time. This allows the user to view in real time the shape change of the object and to analyze the deformations that have taken place.

An example of how the system works is shown in Figure 6. 


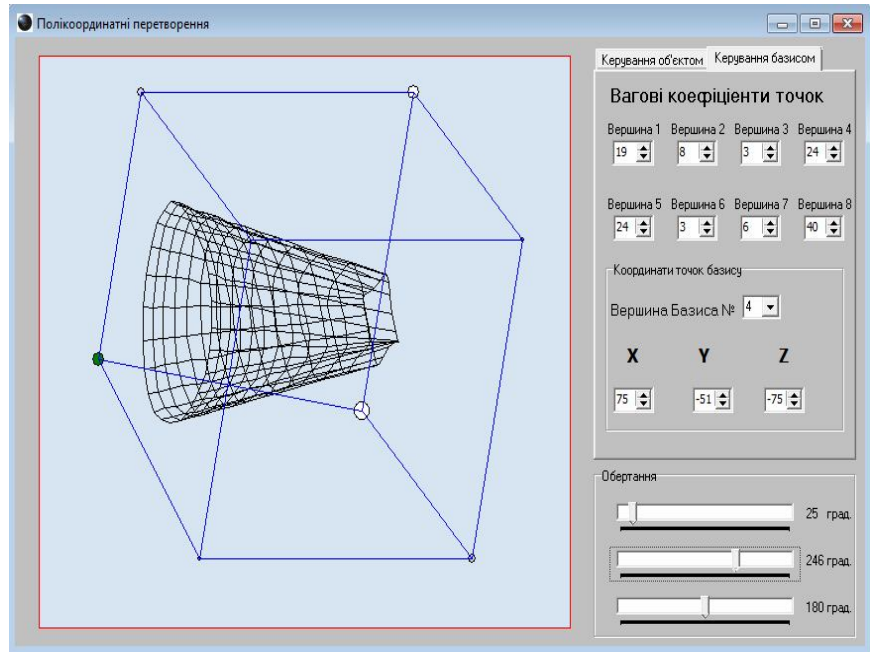

Fig. 6. Deformation of an object after changing the coordinates of the basis points

As can be seen from Figure 6, the user can deform the object and get the shape he needs, by simply manipulating the controls.

5. Conclusions. Studies have shown that polycoordinate transformations can not only model the shape of deformed objects with the ability to visually track these processes, but also construct technical objects such as reducers - adapters with different cross-sections at the ends. In the process, a computer system was created whereby the user could deform the object and get the shape it needed by simply manipulating the controls, which can be useful in the process of producing gearboxes.

\section{REFERENCES}

1. Badaiev Yu.I., Sydorenko Yu.V. Politkanynni peretvorennia v tochkovomu vyznachenni. Prykladnaia heometryia y ynzhenernaia hrafyka. Trudy / Tavrycheskaia hosudarstvennaia ahrotekhnycheskaia akademyia, Vyp. 4, T.8, Melytopol, THATA (1998), S. 21-23.

2. Badaiev Yu.I., Sydorenko Yu.V. Konstruiuvannia heometrychnykh obiektiv zasobamy politochkovykh peretvoren. - Prykladna heometriia ta inzhenerna hrafika, Vyp. 66, K.:KDTUBA (2000), S. 44-47.

3. Sydorenko Yu.V., Dudnyk V.Yu. Udoskonalennia modeli rehuliuvannia vodostoku vodoskhovyshch za dopomohoiu deformatsiinoho modeliuvannia. Zbirnyk naukovykh prats «Suchasni problemy modeliuvannia». Melitopol: Vydavnytstvo MDPU im. B. Khmelnytskoho (2017), S. 130-136.

4. Sydorenko Iu. V., Kryvda O.V., Antoniuk K. V. Systems of the burning edge visualization and determination of the forest fire damage // Innovation and information technologies in the social and economic development of society. Monografia Pod red nauk.: Oleksandr Nestorenko, Magdalena Wierzbik - Strońska, wyższa szkoła techniczna w Katowicach (2018), pp. 58-70. 
Сидоренко Ю.В., Кривда О.В., Лещинська І.В.

СИСТЕМА МОДЕЛЮВАННЯ КОНСТРУКТИВНИХ ЕЛЕМЕНТІВ ВЕНТИЛЯЦІЙНИХ СИСТЕМ ЗАСОБАМИ ПОЛІКООРДИНАТНИХ ПЕРЕТВОРЕНЬ

Дослідження присвячене необхідності створення системи моделювання геометричних об'єктів, яка дозволила б вирішити ряд завдань, що виникають при конструюванні та проектуванні в будівництві, а саме у вентиляційних системах. Завдання вирішується 3 використанням політочкових перетворень. За допомогою деформаційного моделювання можна відображати процеси зміни форми геометричних об'єктів без певного виду аналітичного представлення, користуючись тільки параметрами динамічної деформації. Зміну форми об'єкта викликає деформація простору, в якому знаходиться об'єкт. Представником даного класу моделей $\epsilon$ політочкові перетворення. На основі апарату політочкових перетворень була створена комп'ютерна система моделювання геометричних об'єктів, яка дозволяє спростити процеси конструювання поверхонь 3 різними видами перерізів.

Ключові слова: деформаційне моделювання; політочкові перетворення; комп'ютерне моделювання, вентіляційна система; редуктор.

Сидоренко Ю.В., Кривда Е.В., Лешинская И.В.

\section{СИСТЕМА МОДЕЛИРОВАНИЯ КОНСТРУКТИВНЫХ ЭЛЕМЕНТОВ ВЕНТИЛЯЦИОННЫХ СИСТЕМ СРЕДСТВАМИ ПОЛИКООРДИНАТНЫХ ПРЕОБРАЗОВАНИЙ}

Исследование посвящено необходимости создания системы моделирования геометрических объектов, которая позволила бы решить ряд задач, возникающих при конструировании и проектировании в строительстве, а именно в вентиляционных системах. Задача решается с использованием политочечных преобразований. $\mathrm{C}$ помощью деформационного моделирования можно отображать процессы изменения формы геометрических объектов без определенного вида аналитического представления, пользуясь только параметрами динамической деформации. Изменение формы объекта вызывает деформацию пространства, в котором находится объект. Представителем данного класса моделей являются политочечные преобразования. На основе аппарата политочечных преобразований была создана компьютерная система моделирования геометрических объектов, которая позволяет упростить процессы конструирования поверхностей $\mathrm{c}$ различными видами сечений.

Ключевые слова: деформационное моделирование; политочечные преобразования; компьютерное моделирование, вентиляционные системы; редуктор.

УДК 514.18

Сидоренко Ю.В., Кривда О.В., Лещинська І.В. Система моделювання конструктивних елементів вентиляційних систем засобами полікоординатних перетворень // Опір матеріалів і теорія споруд: наук.-тех. збірн. - К.: КНУБА, 2020. - Вип. 104. - С. 221-228.

Дослідження присвячене необхідності створення системи моделювання геометричних об'єктів, яка дозволила б вирішити ряд завдань, що виникають при конструюванні та проектуванні в будівничтві, а саме у вентиляційних системах. Завдання вирішується $з$ використанням політочкових перетворень.

Табл. 0. Іл. 5. Бібліогр. 4 назв.

UDC 514.18

Sydorenko Iu.V., Kryvda O.V., Leshchynska I.V. System of modeling of structural elements of ventilation systems by polycoordinate transformations // Strength of Materials and Theory of Structures: Scientific and technical collected articles. - Kyiv: KNUBA, 2020. - Issue. 104. - P. 221228.

The research is devoted to the need to create a system of modeling geometric objects that would solve a number of problems that arise in the design and design in construction, namely in ventilation systems. The problem is solved using polypoint transformations.

Tab. 0. Fig. 5. Ref. 4. 


\section{УДК 514.18}

Сидоренко Ю.В., Кривда Е.В., Лещинская И.В. Система моделирования конструктивных элементов вентиляционных систем средствами поликоординатных преобразований // Сопротивление материалов и теория сооружений: науч.-тех. сборн. - К.: КНУСА, 2020. Вып. 104. - С. 221-228. - Англ.

Исследование посвящено необходимости создания системы моделирования геометрических объектов, которая позволила бы решить ряд задач, возникающих при конструировании и проектировании в строительстве, а именно в вентиляционных системах. Задача решается с использованием политочечных преобразований.

Табл. 0. Ил. 5. Библиогр. 4 назв.

Автор (вчена ступень, вчене звання, посада): кандидат технічних наук, доцент кафедри автоматизації проектування енергетичних процесів і систем Національного технічного університету України «Київський політехнічний інститут імені Ігоря Сікорського», СИДОРЕНКО Юлія Всеволодівна.

Адреса робоча: 03056, Київ, Перемоги 37, Національний технічний університет України «Київський політехнічний інститут імені Ігоря Сікорського», СИДОРЕНКО Юлії Всеволодівні

Робочий тел.: +38(044) 458-26-99

Мобільний тел.: +38(097) 954-16-32

E-mail: suliko3@ukr.net

ORCID ID: http://orcid.org/0000-0002-1953-0410

Автор (вчена ступень, вчене звання, посада): кандидат економічних наук, доцент кафедри економіки і підприємництва Національного технічного університету України «Київський політехнічний інститут імені Ігоря Сікорського», КРИВДА Олена Віталіївна

Адреса робоча: 03056, Київ, Перемоги 37, Національний технічний університет України «Київський політехнічний інститут імені Ігоря Сікорського», КРИВДІ Олені Віталіївні

Робочий тел.: +38(044) $204-85-08$

Мобільний тел.: +38(097)937-42-12

E-mail: elcandy@ukr.net

ORCID ID: http://orcid.org/0000-0003-4398-6298

Автор (вчена ступень, вчене звання, посада): здобувач кафедри менеджменту в будівництві КНУБА, ЛЕЩИНСЬКА Ірина Василівна

Адреса робоча: 03680 , м. Київ, Повітрофлотський проспект 31, Київський національний університет будівництва і архітектури, ЛЕЩИНСЬКІЙ Ірині Василівні

Робочий тел.: +38(044) 241-55-15.

Мобільний тел.: +38(063) 228-24-06.

E-mail: ayrinochka@gmail.com

ORCID ID: http://orcid.org/0000-0002-8737-4595 